\title{
Kontribusi Status Gizi dan Kemampuan Motorik terhadap Kesegaran Jasmani Siswa Sekolah Dasar
}

\author{
S. Sepriadi \\ Program Studi Pendidikan Jasmani Kesehatan dan Rekreasi, Fakultas Ilmu Keolahragaan Universitas \\ Negeri Padang. Jalan Prof. Dr. Hamka Air Tawar Barat Padang 25131, Indonesia \\ Email: sepriadi65@gmail.com \\ Received: 4 August 2017; Revision: 2 October 2017; Accepted: 10 October 2017
}

\begin{abstract}
Abstrak
Penelitian ini didasarkan karena masih rendahnya kesegaran jasmani siswa Sekolah Dasar. Hal ini disebabkan berbagai faktor diantaranya gizi dan motorik. Penelitian ini bertujuan mengetahui: (1) kontribusi status gizi terhadap kesegaran jasmani Siswa Sekolah Dasar. (2) kontribusi kemampuan motorik terhadap kesegaran jasmani Siswa Sekolah Dasar, dan (3) kontribusi status gizi dan kemampuan motorik terhadap kesegaran jasmani Siswa Sekolah Dasar. Jenis penelitian adalah rancangan penelitian observasional dengan pendekatan korelasional. Populasi penelitian ini adalah seluruh siswa Sekolah Dasar Negeri 06 Pulai Anak Air Kota Bukittingi. Teknik pemgambilan sampel dalam penelitian ini digunakan teknik purposive sampling. Instrument yang digunakan adalah Tes Kesegaran Jasmani Indonesia untuk mengukur kesegaran jasmani siswa, Status gizi dengan Indeks Massa Tubuh berdasarkan Usia (IMT/U) dan Kemampuan Motorik dengan tes kemampuan motorik. Teknik analisis data yang digunakan adalah analisis korelasi dan regresi sederahana serta ganda. Hasil penelitian ini menunjukkan bahwa: (1) Status gizi memberikan kontribusi terhadap Kesegaran Jasmani Siswa Sekolah Dasar sebesar 14.08\%. (2) Kemampuan motorik memberikan kontribusi terhadap Kesegaran Jasmani Siswa Sekolah Dasar sebesar 64.32\%, dan (3) Status gizi dan kemampuan motorik memberikan kontribusi secara bersama-sama terhadap Kesegaran Jasmani Siswa Sekolah Dasar sebesar $69.38 \%$
\end{abstract}

Kata Kunci: status gizi, kemampuan motorik, dan kesegaran jasmani

\section{The Contribution of Nutritional Status and Motor Skill on Physical Fitness of Student in Elementary School}

\begin{abstract}
This research is based on the low physical fitness of elementary school students. This is due to various factors such as nutrition and motoric. The Study aimed determine: (1) the contribution between nutritional status on Physical Fitness of The Students at Elementary School, (2) the contribution between motor skill on Physical Fitness of The Students at Elementary School, and (3) the contribution of Nutritional status and Motor skill on Physical Fitness of The Students at Elementary School. The research is analysis corelational design. The population of the research was students at Public Elementary school 06 Pulai Anak Air Bukittinggi. The samples were taken with purposive sampling technique. The data were collected Indonesian Physical fitness test for measuring physical fitness, Nutritional status as well as body mass index and motor skill by using motor skill test. The data analysis technique used is correlation analysis and simple and double regression. The results of thi study indicate that: (1) Nutritional status contributed toward physical fitness of students at Elementary school 06 Pulai Anak Air Bukittinggi about 14.08\%. (2) motor skill contributed toward physical fitness about $64.32 \%$, and (3) nutritional status and motor skill contributed along toward physical fitness of students at Elementary school 06 Pulai Anak Air Bukittinggi about 69.38\%
\end{abstract}

Keywords: nutritional status, motor skill, physical fitness

How to Cite: Sepriadi, S. (2017). Kontribusi status gizi dan kemampuan motorik terhadap kesegaran jasmani siswa sekolah dasar. Jurnal Keolahragaan, 5(2), 194-206. doi:http://dx.doi.org/10.21831/jk.v5i2.15147

Permalink/DOI: http://dx.doi.org/10.21831/jk.v5i2.15147 


\section{PENDAHULUAN}

Pendidikan pada dasarnya mempunyai peranan penting dalam mencerdaskan kehidupan bangsa dimana sasarannya adalah untuk meningkatkan kualitas manusia Indonesia, baik sosial, spiritual, dan intelektual serta kemampuan yang professional sebagai mana yang terdapat dalam Undang-Undang Republik Indonesia No. 20 Tahun 2003 yang tercantum pada pasal 3 tentang sistem pendidikan nasional, dimana fungsi dan tujuan pendidikan nasional itu adalah sebagai berikut: "Pendidikan Nasional berfungsi mengembangkan kemampuan dan watak serta peradapan bangsa yang bermatabat dalam rangka mencerdaskan kehidupan bangsa, bertujuan untuk berkembangnya potensi peserta didik agar jadi manusia yang beriman dan bertaqwa kepada Tuhan Yang Maha Esa, berakhlak mulia, sehat, beriman, cakap, kreatif, mandiri dan menjadi warga Negara yang demokratif secara bertanggung jawab". (Presiden Republik Indonesia, 2003).

Berdasarkan kutipan tersebut jelaslah bagi kita bahwa pendidikan tersebut sangat mempunyai peranan penting untuk mewujudkan watak seseorang yang akhirnya menjadi cerdas, yang beriman dan bertaqwa kepada Tuhan yang Maha Esa, berakhlak mulia, sehat jasmani dan rohani dapat dilakukan dengan berbagai cara baik di lingkungan tempat tinggal maupun di sekolah. Kesegaran adalah kemampuan seseorang untuk hidup dengan harmonis dan penuh semangat. Manusia yang segar adalah manusia yang berpandangan sehat dan cerdas terhadap kehidupan dan masa depannya. Ia mempunyai harga diri dan menyukai pergaulan dengan sesama manusia lainnya serta hidup bahagia dengan mereka.

Kesegaran jasmani adalah suatu kemampuan yang menitikberatkan pada fungsi-fungsi fisiologis, yaitu kemampuan jantung, pembuluh darah, paru, dan otot yang berfungsi pada efisiensi yang optimal. Untuk itu dalam meningkatkan kesegaran jasmani anak-anak, tentu orang tua harus menseleksi bentuk-bentuk permainan yang di lakukan anak dan dapat merangsang komponen-komponen kesegaran jasmani seperti: ketahanan jantung paru, kekuatan otot, komposisi tubuh, dan fleksibel (Gusril, 2004, p. 184).

Menurut Sutarman dalam Arsil (1999, p. 9) mengemukakan bahwa kesegaran jasmani adalah suatu aspek, yaitu aspek fisik dari kesegaran yang menyeluruh (total fitness), yang memberikan kesanggupan kepada seseorang untuk menjalankan hidup yang produktif dan dapat menyesuaikan diri pada tiap-tiap pembebanan fisik (physical stress) yang layak.

Berdasarkan kutipan yang dikemukakan, berarti kesegaran jasmani marupakan cermin dari kemampuan fungsi sistem-sistem dalam tubuh yang dapat mewujudkan suatu peningkatan kualitas hidup dalam setiap aktifitas fisik.

Kesegaran jasmani sangat dibutuhkan oleh setiap siswa untuk memperoleh ketangkasan, kesanggupan serta kemampuan belajar yang tinggi. Salah satu jalan untuk memelihara atau meningkatkan kesegaran jasmani dengan melakukan olahraga secara teratur dan aktifitas fisik sehari-hari yang bermanfaat untuk kesehatan. Sehubungan dengan itu, perlu digiatkan lagi pendidikan jasmani dan kesehatan di sekolah. Jadi, mata pelajaran pendidikan jasmani dan kesehatan perlu dilaksanakan di setiap sekolah sesuai dengan kurikulum pendidikan untuk membina kesegaran jasmani, kesehatan, dan rohani anak didik.

Selain itu, kesegaran jassmani dan juga kondisi fisik sangat mempengaruhi penguasaan siswa terhadap cabang olahraga. Hal ini sesuai dengan Ihsan (2014, p. 307) yang menjelakan "Physical condition is an important thing for a learner since it is a basic foundation to master techniques, tactics, strategies and psychical condition"

Pembinaan kesegaran jasmani dan kesehatan disekolah, perlu mempertimbangkan aspek kondisi sekolah, lingkungan geografis, dan status ekonomi orang tua siswa. Sebab, kondisi suatu tingkat sekolah belum tentu sama dengan sekolah lainnya. Ada sekolah yang dapat menyediakan sarana dan prasarana pendukung yang memadai, tetapi ada juga sekolah yang tidak dapat menyediakan sarana pendukung pendidikan kesegaran jasmani dan kesehatan. Selain itu, Kondisi geografis juga ikut mempengaruhi tingkat kesegaran jasmani.

Siswa yang bersekolah yang berada di daerah daratan rendah. Kemungkinan akan memiliki tingkat kesegaran jasmani yang berbeda dengan siswa yang bersekolah disekolah yang berada didaerah perbukitan. Siswa yang kesekolah dengan berjalan kaki juga akan memiliki tingkat kesegaran jasmani yang berbeda dengan siswa yang setiap harinya naik kendaraan. Begitu juga dengan tingkat ekonomi orang tua siswa. Siswa yang memiliki orangtua dengan tingkat ekonomi lebih baik, kemungkinan akan memperoleh gizi yang lebih baik dibandingkan 
dengan siswa yang tingkat kesegaran ekonomi orang tuanya rendah.

Siswa Sekolah Dasar Negeri 06 Pulai Anak Air Kota Bukittinggi. Jika dilihat dari geografis berada pada dataran tinggi, dari sarana dan prasarana yang ada di Sekolah kurang memadai. Selain itu keadaan status gizi anak kadang kurang menjadi perhatian yang serius, setelah dilihat dari makanan dan asupan gizi yang di konsumsi setiap pagi disekolah. Kesegaran jasmani memiliki peranan penting dalam kegiatan sehari-hari siswa, karena kesegaran jasmani yang baik diperlukan oleh siswa baik dalam mengikuti proses pembelajaran di sekolah maupun dalam pencapaian prestasi di luar sekolah. Secara umum kesegaran jasmani dapat diartikan sebagai kemampuan seseorang melakukan kerja sehari-hari secara efisien tanpa menimbulkan kelelahan yang berlebihan, sehingga masih menikmati waktu luang. Betapa pentingnya kesegaran jasmani bagi siswa, karena apabila kesegaran jasmani siswa itu bagus, maka dapat membantu siswa dalam proses pembelajaran dengan tanpa adanya rasa lelah, lesu dan jenuh dalam proses belajar.

Siswa Sekolah Dasar Negeri 06 Pulai Anak Air Kota Bukittinggi juga melakukan kegiatan pembelajaran Penjasorkes, yang juga menjalankan kurikulum penjasorkes secara teratur. Namun berdasarkan pengamatan penulis pada saat siswa melakukan kegiatan Proses Belajar Mengajar penjasorkes banyak anak yang malas melakukan aktivitas fisik, gerak yang kurang cukup, dan lebih cenderung duduk. Selain itu anak cepat lelah dan cepat mengalami kelelahan, yang ditandai seringnya menguap pada saat pembelajaran Penjasorkes.

Banyak faktor yang mempengaruhi siswa dalam pembelajaran penjasorkes diantaranya motivasi instrinsik siswa, status ekonomi siswa, keadaan lingkungan, aktivitas fisik siswa, kemampuan motorik siswa, Status gizi, letak lingkungan sekolah, proses pembelajaran penjasorkes di sekolah, strategi pembelajaran, materi yang di ajarkan, kemampuan guru penjas, sarana dan prasarana, dukungan orang tua dan tingkat keturunan (genetik).

Menurut Mikdar (2006, p. 45) kesegaran jasmani adalah kemampuan tubuh seseorang untuk melakukan tugas dan pekerjaan seharihari tanpa menimbulkan kelelahan yang berarti, sehingga tubuh masih memiliki sim-panan tenaga untuk mengatasi beban kerja tambahan. Untuk peningkatan kebugaran jas-mani dapat dilakukan dengan cara bermain seperti lompat tali. Permainan lompat tali secara fisik akan menjadikan anak lebih kuat dan tangkas. Belum lagi manfaat emosional, intelek-tual, dan sosialnya yang akan berkembang dalam diri siswa tersebut". Lebih lanjut Physical fitness (kesegaran jasmani) yaitu badan yang sehat dan segar. Jadi, kesegaran jasmani sebagai suatu konsep yang mempunyai ruang lingkup yang cukup luas yang salah satunya merupakan kemampuan tubuh dalam beradaptasi terhadap beban fisik yang diberikan kepada tubuh saat melakukan aktifitas berlebih tanpa merasakan kelelahan..

Dari kutipan dan penjelasan tersebut, maka semakin jelaslah bahwa kesegaran jasmani merupakan suatu kondisi fisik tubuh dalam mempertahankan atau menyesuaikan fungsi dari alat-alat fisiologis agar dapat beradaptasi dengan lingkungan, sehingga aktifitas yang di lakukan sehari-hari tidak mengalami hambatan, karena tubuh telah mempunyai kondisi yang baik dalam menghadapi hambatan-hambatan tersebut. Makanya seseorang mampu melawan pengaruhpengaruh luar dan tidak mengurangi efesiensi kondisi badan.

Oleh karena itu kesegaran jasmani merupakan suatu yang dipengaruhi oleh aktifitas fisik dan latihan olahraga yang dilakukan seseorang maka semakin baik pula tingkat kesegaran jasmaninya. Melakukan aktifitas fisik dan latihan olah raga akan meningkatkan kemampuaan tubuh dalam mengkonsumsi oksigen secara maksimal, maka secara otomatis akan berpengaruh terhadap kesegaran jasmani.

Jadi, kesegaran jasmani itu adalah aspekaspek kemampuan fisik yang dapat menunjang kesuksesan siswa dalam melakukan berbagai aktivitas dalam kehidupan sehari-hari tanpa mengakibatkan kelelahan yang berarti. Kegiatan itu dapat berupa pekerjaan sehari-hari dan untuk keperluaan mendadak atau pekerjaan itu dilakukan dalam waktu senggang, karena semakin tinggi tingkat kesegaran jasmani, yang memiliki seseorang maka semakin besar pula kemungkinannya untuk dapat meyesuaikan suatu pekerjaan dan semakin besar pula untuk dapat menikmati kehidupan.

Menurut Kiram (1992, p. 5) konsep motorik adalah: "Penampilan yang kongkrit maksudnya adalah gerakan sebagai sesuatu yang dapat diamati, sedangkan motorik adalah suatu proses yang tidak dapat diamati dan merupakan penyebab terjadinya gerak".

Kirkendall dalam Gusril, Kiram, Aziz, Hos, \& Darmela (2006, p. 13) mengemukakan 
bahwa: "Kemampuan motorik adalah merupakan kualitas kemampuan seseorang yang dapat mempermudah dalam melakukan kemampuan gerak". Kemampuan Motorik berasal dari bahasa Inggris yaitu Motor Ability, gerak (motor) merupakan suatu aktivitas yang sangat penting bagi manusia, karena dengan gerak (motor) manusia dapat meraih sesuatu yang menjadi harapannya. Menurut Lutan (1988, p. 96), mengatakan bahwa "kemampuan motorik adalah kapasitas seseorang yang berkaitan dengan pelaksanaan dan peragaan suatu keterampilan yang relatif melekat setelah masa kanak-kanak". Menurut Sukadiyanto (1997, p. 70), mengatakan bahwa "kemampuan motorik adalah suatu kemampuan seseorang dalam menampilkan keterampilan gerak yang lebih luas serta diperjelas bahwa kemampuan motorik suatu kemampuan umum yang berkaitan dengan penampilan berbagai keterampilan atau tugas gerak". Berdasarkan beberapa kutipan tersebut, dapat diambil kesimpulan bahwa kemampuan motorik adalah kemampuan-kemampuan unjuk kerja/tampilan seseorang yang dipengaruhi oleh faktor-faktor kekuatan, kecepatan, daya tahan dan koordinasi, dengan demikian akan lebih mempermudah dalam melakukan kemampuan gerak.

Gerakan motorik melibatkan aktivitas otot tangan, kaki, dan seluruh tubuh anak. Gerakan ini mengandalkan kematangan dan koordinasi. Berbagai gerakan motorik kasar yang dicapai anak tentu sangat berguna bagi kehidupan kelak. Misalnya anak dibiasakan untuk terampil berlari atau memanjat jika mereka sudah lebih besar akan senang berolahraga. Ada tiga jenis gerakan yang dapat dilakukan dalam motorik, yaitu gerak lokomotor, gerak nonlokomotor, dan gerak manipulatif.

Perkembangan motorik merupakan salah satu faktor yang sangat penting dalam perkembangan individu secara keseluruhan. Beberapa pengaruh perkembangan motorik terhadap konstelasi perkembangan individu dipaparkan oleh Hurlock, Istiwidayanti, Sijabat, \& Soedjarwo (1990) sebagai berikut: (1) Melalui kemampuan motorik, anak dapat menghibur dirinya dan memperoleh perasaan senang. Seperti anak merasa senang dengan memiliki kemampuan memainkan boneka, melempar dan menangkap bola atau memainkan alat-alat mainan. (2) Melalui kemampuan motorik, anak dapat beranjak dari kondisi tidak berdaya pada bulan-bulan pertama dalam kehidupannya, ke kondisi yang independent. Anak dapat bergerak dari satu tempat ke tempat lainnya dan dapat berbuat sendiri untuk dirinya. Kondisi ini akan menunjang perkembangan rasa percaya diri. (3) Melalui perkembangan motorik, anak dapat menyesuaikan dirinya dengan lingkungan sekolah. Pada usia prasekolah atau usia kelas-kelas awal Sekolah Dasar, anak sudah dapat dilatih menulis, menggambar, melukis, dan barisberbaris. (4) Melalui perkembangan motorik yang normal memungkinkan anak dapat bermain atau bergaul dengan teman sebayanya, sedangkan yang tidak normal akan menghambat anak untuk dapat bergaul dengan teman sebayanya bahkan dia akan terkucilkankan atau menjadi anak yang fringer (terpinggirkan), dan (5) Perkembangan kemampuan motorik sangat penting bagi perkembangan self-concept atau kepribadian anak.

Menurut Wirjatmadi (1998, p. 3) Status gizi merupakan ukuran keadaan gizi pada seseorang dan juga pada sekelompok orang. Sedangkan menurut Supariasa, Bakri, \& Fajar (2002) "Status gizi adalah ekspresi dari keadaan keseimbangan dalam bentuk variabel tertentu, atau perwujudan dari nuriture dalam bentuk variabel tertentu, contoh: Gondok endemik merupakan keadaan tidak seimbangnya pemasukan dan pengeluaran yodium dalam tubuh". Lebih lanjut menurut Kamus Besar Bahasa Indonesia dijelaskan secara bahasa bahwa status gizi terdiri dari kata status dan gizi, yang dapat diartikan sebagai keadaan atau kedudukan zat makanan pokok dalam tubuh seseorang yang diperlukan bagi tubuh untuk pertumbuhan dan kesehatan (Departemen Pendidikan Nasional, 2008).

Status gizi menurut Almatsier $(2002$, p. 3) adalah: "Keadaan tubuh sebagai akibat konsumsi makanan dan penggunaan zat-zat gizi, dibedakan antara status gizi buruk, kurang, baik, dan lebih". Lebih lanjut Berg \& Nur (1986) menjelaskan bahwa: "Status gizi merupakan keadaan tubuh yang menggambarkan status kesehatan seseorang atau masyarakat di dalam kehidupan sehari-hari akibat interaksi makanan, tubuh dan lingkungan.

Berdasarkan beberapa kutipan di atas dapat disimpulkan bahwa status gizi adalah klasifikasi atau ukuran keadaan gizi seseorang yang diakibatkan oleh konsumsi, penyerapan, dan penggunaan zat gizi makanan.

Kebutuhan gizi setiap anak akan berbedabeda, ini menyangkut terhadap faktor fisiologis pada anak dan lingkungan dimana mereka berada, serta berhubungan sengan umur, berat badan, jenis kelamin, iklim dan aktivitas yang 
dilakukan anak. Adapun makanan yang mengandung gizi yang dianjurkan yaitu: (a) karbohidrat; (b) protein; (c) lemak; (d) vitamin; (e) mineral; dan (f) air.

Status gizi baik atau optimal terjadi bila tubuh memperoleh cukup zat-zat gizi, dan digunakan secara efisien sehingga memungkinkan pertumbuhan fisik, perkembangan otak, kemampuan aktivitas fisik dan kesehatan secara umum pada tingkat setinggi mungkin. Pada umumnya kondisi status gizi yang baik memungkinkan seseorang melakukan aktivitas yang tinggi.

Jadi, definisi dari Status gizi adalah kondisi atau ukuran keadaan gizi seseorang yang diakibatkan oleh konsumsi, penyerapan, dan penggunaan zat gizi makanan. Status gizi diukur dengan penilaian antropometri secara langsung yaitu dengan perhitungan Indeks Massa Tubuh (IMT).

\section{METODE}

Penelitian ini adalah penelitian observasional dengan menggunakan pendekatan korelasi yang bertujuan untuk menyelidiki seberapa jauh hubungan variabel-variabel yang diperoleh berkaitan dengan variabel lain berdasarkan kepada besarnya koefesien korelasi. Hal ini sejalan dengan apa yang diungkapkan Suryabrata $(2000$, p. 82) yang mengatakan bahwa: "tujuan penelitian korelasional adalah untuk mendeteksi sejauh mana variasi-variasi pada suatu faktor berkaitan dengan variasi-variasi pada satu atau lebih faktor lain berdasarkan pada koefisien korelasi".

Penelitian ini berusaha mengungkap hubungan antar variabel sesuai dengan keadaan yang sebenarnya. Analisis dilanjutkan dengan menghitung besarnya kontribusi variabel bebas (prediktor) terhadap variabel terikat (kriterium), melalui indeks determinasi, yaitu $\mathrm{r}^{2} \times 100 \%$.

Penelitian ini dilaksanakan di SD Negeri 06 Pulai Anak Air Kota Bukittinggi. Penelitian ini dilaksanakan pada Aptril 2016. Populasi dalam penelitian ini adalah seluruh siswa SD Negeri 06 Pulai Anak Air Kota Bukittingi dengan jumlah 181 orang. Pengambilan sampel dilakukan dengan teknik purposive sampling. Sehingga sampel yang diambil adalah siswa Putera kelas 4 dan 5. Hal ini karena terdapat perbedaan kemampuan antara siswa putera dan puteri dan yang menjadi sampel hanya siswa putera saja dengan jumlah 34 orang.
Untuk mengukur Kesegaran jasmani siswa tes yang digunakan adalah tes kesegaran jasmani Indonesia (TKJI) usia 10-12 tahun. Tes Kemampuan motorik yang digunakan adalah Barrow Motor Ability Test dengan bentuk tes yang dilaksanakan adalah (1) Standing Broad Jump, (2) Soft Ball Throw (3) Zig-zag Run, (4) Wall Pass, (5) Medicine Ball-Put, (6) Lari 60 yard. Dan untuk mengukur status gizi dengan indeks massa tubuh berdasarkan usia (IMT/U).

Teknik analisis data yang digunakan adalah teknik analisis korelasi sederhana dan ganda. Hipotesis 1, dan 2 dianalisis dengan korelasi dan regresi sederhana, sedangkan hipotesis 3 dianalisis dengan korelasi dan regresi ganda.

Sebelum melakukan analisis terhadap data di atas, dilakukan uji persyaratan, yaitu: (1) Uji normalitas untuk mengetahui apakah data berasal dari populasi yang berdistribusi normal, dilakukan dengan uji normalitas data taksiran dengan Uji Lilliefors. (2) Uji homogenitas dengan menggunakan uji homogenitas varians galat regresi dengan Uji Bartlet. (3) Uji linearitas regresi $\mathrm{X} 1$ atas $\mathrm{Y}$, dan $\mathrm{X} 2$ atas $\mathrm{Y}$ menggunakan teknik regresi sederhana. (4) Uji independensi antara variabel-variabel bebas. (5) Analisis korelasi sederhana dan regresi ganda, analisis ini digunakan untuk mengetahui kontribusi variabel status gizi (X1) dan kemampuan motorik (X2) secara bersama-sama terhadap kesegaran jasmani (Y).

\section{HASIL DAN PEMBAHASAN}

\section{Deskripsi Data}

Pada bagian ini akan dipaparkan deskripsi data hasil pengukuran terhadap seluruh subjek penelitian. Data penelitian ini terdiri dari: kesegaran jasmani siswa sebagai variabel terikat $(\mathrm{Y})$, status gizi $\left(\mathrm{X}_{1}\right)$ dan kemampuan motorik $\left(\mathrm{X}_{2}\right)$ sebagai variabel bebas.

Untuk lebih jelasnya gambaran keadaan masing-masing data dalam kelompok dapat dilihat diskripsi sebagai berikut:

\section{Status Gizi $\left(\mathrm{X}_{1}\right)$}

Analisis variabel status gizi siswa, diperoleh rata-rata $=17,86$, standar deviasi $=2,46$, nilai tertinggi 24,87 , dan nilai terendah $=15,01$. Distribusi frekuensi dapat digambarkan dalam Tabel 1. 
Jurnal Keolahragaan 5 (2), September 2017 - 199

S. Sepriadi

Tabel 1. Distribusi Frekuensi Status Gizi Siswa $\left(\mathrm{X}_{1}\right)$

\begin{tabular}{ccccc}
\hline \multirow{2}{*}{ No. } & IMT & Kelas Interval & \multicolumn{2}{c}{ Frekuensi } \\
\cline { 4 - 5 } & & $<-3$ SD & Absolut & Relatif (\%) \\
2. & Sangat Kurus & -3 SD - <-2 SD & 0 & 0,00 \\
3. & Kurus & -2 SD - 1 SD & 0,00 \\
4. & Normal & $>1$ SD - 2 SD & 20 & 88,24 \\
5. & Gemuk & $>2$ SD & 2 & 5,88 \\
& Obesitas & & $\mathbf{3 4}$ & 5,88 \\
\hline
\end{tabular}

$\square$ Series $\mid \begin{array}{cc}\text { Series1; Sarba\$eries1; Kurus; } \\ \text { Kurus; } 0 & 0\end{array}$

Series1;

Normal; 30

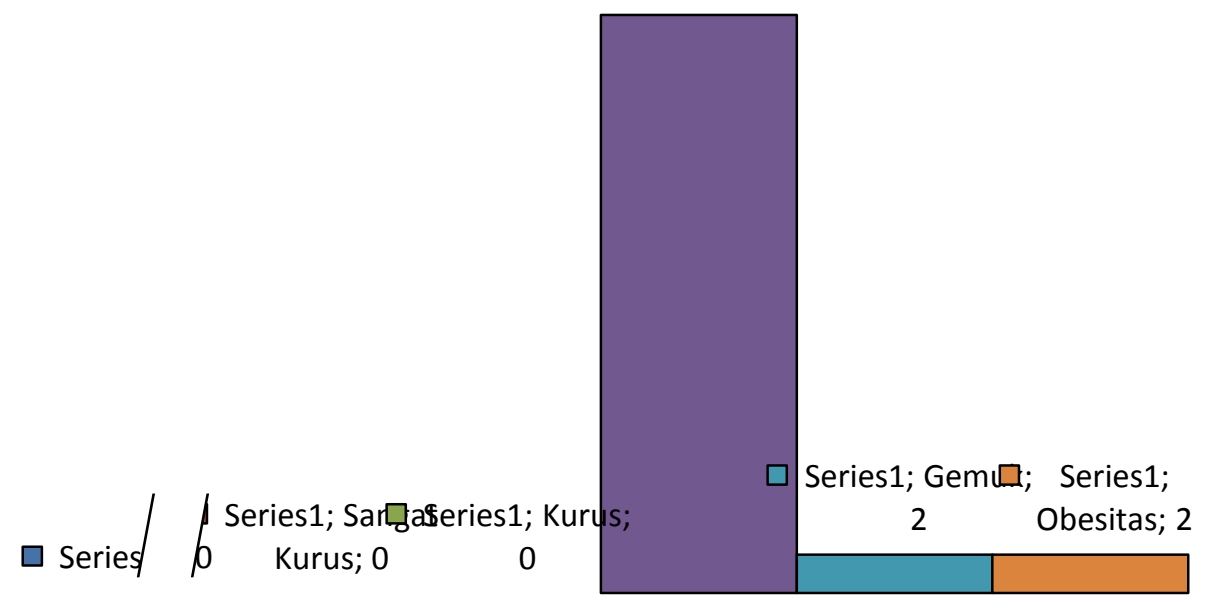

Gambar 1. Histogram Status Gizi Siswa $\left(\mathrm{X}_{1}\right)$

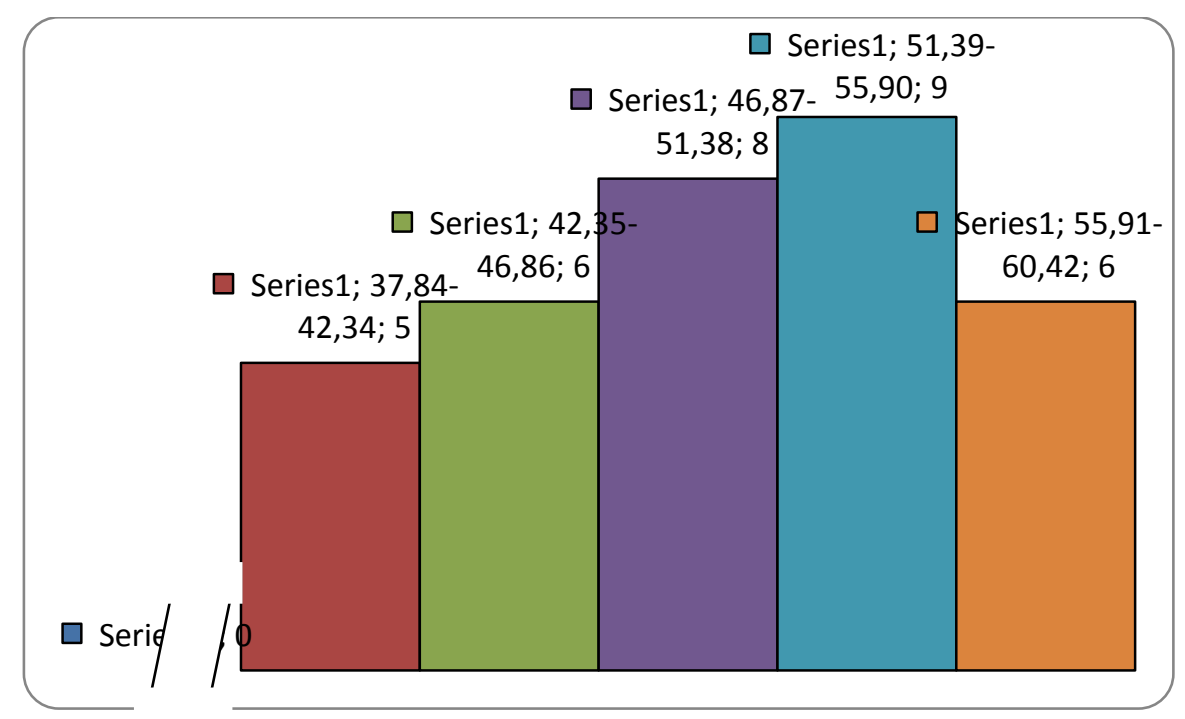

Gambar 2. Histogram Kemampuan Motorik Siswa $\left(\mathrm{X}_{2}\right)$ 


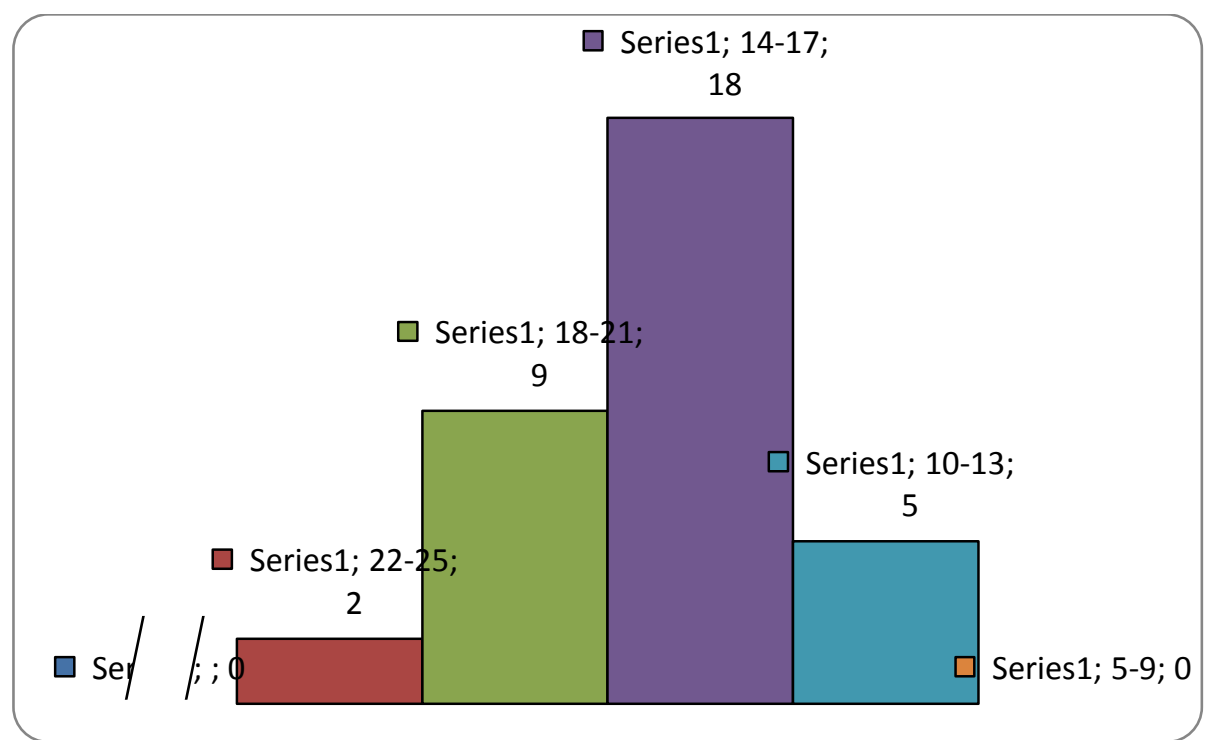

Gambar 3. Histogram Data Kesegaran Jasmani Siswa (Y)

Tabel 1 menunjukkan bahwa terdapat sebanyak 30 orang $(88.24 \%)$ berada pada kategori normal, 2 orang $(5.88 \%)$ berada pada kategori gemuk, dan 2 orang $(5.88 \%)$ berada pada kategori obesitas. Untuk lebih jelas hasil perhitungan dan penjabaran distribusi frekuensi data status gizi siswa dapat dilihat pada Gambar 1.

\section{Kemampuan Motorik Siswa (X2)}

Dari hasil pengukuran sampel dalam kelompok ini, diperoleh nilai tertinggi 60.38 , nilai terendah 37.84 , rata-rata 50.00 , kemudian simpangan baku 6.12. Distribusi frekuensi dapat digambarkan dalam Tabel 2.

Tabel 2. Distribusi Frekuensi Kemampuan Motorik Siswa $\left(\mathrm{X}_{2}\right)$

\begin{tabular}{cccc}
\hline \multirow{2}{*}{ No. } & \multirow{2}{*}{ Kelas Interval } & \multicolumn{2}{c}{ Frekuensi } \\
\cline { 3 - 4 } & & Absolut & Relatif (\%) \\
\hline 1. & $37,84-42,34$ & 5 & 14,71 \\
2. & $42,35-46,86$ & 6 & 17,65 \\
3. & $46,87-51,38$ & 8 & 23,53 \\
4. & $51,39-55,90$ & 9 & 26,47 \\
5. & $55,91-60,42$ & 6 & 17,65 \\
& Jumlah & 34 & $100 \%$ \\
\hline
\end{tabular}

Tabel 2 menunjukkan bahwa terdapat sebanyak 5 orang $(14.71 \%)$ pada kelompok $37.84-42.34$, 6 orang $(17.65 \%)$ pada kelompok $42.35-46.86$, 8 orang $(23.53 \%)$ pada kelompok $46.87-51.38$, 9 orang $(26.47 \%)$ pada kelompok $51.39-55.90$, dan 6 orang $(17.65 \%)$ pada kelompok 55.91-60.42. Untuk lebih jelas tentang hasil pengukuran dan penjabaran distribusi frekuensi kemampuan motorik siswa dapat dilihat pada Gambar 2.
Kesegaran Jasmani Siswa (Y)

Dari hasil pengukuran sampel dalam kelompok ini diperoleh nilai tertinggi 22 , nilai terendah 12. Rata-rata 15.94, kemudian simpangan baku 2.53. Distribusi frekuensi hasil Kesegaran Jasmani Siswa dapat digambarkan dalam tabel 3.

Tabel 3. Distribusi Frekuensi Data Kesegaran Jasmani Siswa (Y)

\begin{tabular}{|c|c|c|c|c|}
\hline \multirow{2}{*}{ No. } & \multirow{2}{*}{ Kategori } & \multirow{2}{*}{$\begin{array}{c}\text { Kelas } \\
\text { Interval }\end{array}$} & \multicolumn{2}{|c|}{ Frekuensi } \\
\hline & & & Absolut & Relatif (\%) \\
\hline 1. & $\begin{array}{c}\text { Baik } \\
\text { Sekali }\end{array}$ & $22-25$ & 2 & 5,88 \\
\hline 2. & Baik & $18-21$ & 9 & 26,47 \\
\hline 3. & Sedang & $14-17$ & 18 & 52,94 \\
\hline 4. & Kurang & $10-13$ & 5 & 14,71 \\
\hline 5. & $\begin{array}{l}\text { Kurang } \\
\text { Sekali }\end{array}$ & $5-9$ & 0 & 0,00 \\
\hline & & Jumlah & 34 & $100 \%$ \\
\hline
\end{tabular}

Tabel 3 menunjukkan bahwa terdapat sebanyak 2 orang $(5.88 \%)$ pada Kategori Baik Sekali, 9 orang (26.47\%) pada Kategori Baik, 18 orang $(52.94 \%)$ pada Kategori sedang, dan 5 orang $(14.71 \%)$ pada Kategori Kurang Seklai. Untuk lebih jelas tentang hasil pengukuran dan penjabaran distribusi frekuensi kesegaran jasmani siswa dapat dilihat pada Gambar 3.

\section{Pengujian Persyaratan Analisis}

Uji Normalitas

Uji normalitas dilakukan dengan menggunakan uji normalitas data galat taksiran dengan uji Liliiefors dengan taraf nyata $(\alpha)=$ 0.05 , kriteria pengujian adalah bahwa $\mathrm{H}_{\mathrm{o}}$ ditolak apabila $\mathrm{L}_{\mathrm{o}}$ yang diperoleh dari data pengamatan 
melebihi $\mathrm{L}_{t}$ dan sebaliknya $\mathrm{H}_{\mathrm{o}}$ diterima apabila $\mathrm{L}_{\mathrm{t}}$ lebih besar dari $\mathrm{L}_{\mathrm{o}}$ secara sederhana dapat digunakan rumus sebagai berikut:

$\mathrm{H}_{\mathrm{o}}=$ ditolak apabila $\mathrm{L}_{\mathrm{o}}>\mathrm{L}_{\mathrm{t}}\left(\mathrm{L}_{\text {tabel }}\right)$

$\mathrm{H}_{\mathrm{a}}=$ diterima apabila $\mathrm{L}_{\mathrm{o}}<\mathrm{L}_{\mathrm{t}}\left(\mathrm{L}_{\text {tabel }}\right)$

Rangkuman hasil perhitungan uji normalitas dapat dilihat pada Tabel 4.

Tabel 4. Rangkuman Hasil Uji Normalitas Data Galat Taksiran dengan Uji Liliiefors

\begin{tabular}{ccccc}
\hline $\begin{array}{c}\text { Persamaan } \\
\text { Regresi }\end{array}$ & $\mathbf{N}$ & $\mathbf{L}_{\mathbf{o}}$ & $\mathbf{L}_{\mathbf{t}}$ & Kesimpulan \\
\hline $\mathrm{Y}$ atas $\mathrm{X}_{1}$ & 34 & 0,1317 & 0.1519 & Normal \\
$\mathrm{Y}$ atas $\mathrm{X}_{2}$ & 34 & 0,1208 & 0.1519 & Normal \\
\hline
\end{tabular}

Keterangan :

$\mathrm{n}$ : jumlah sampel

$\mathrm{L}_{\mathrm{o}}$ : nilai $\mathrm{L}_{\text {obsevasi }}$

$\mathrm{L}_{\mathrm{t}}$ : nilai $\mathrm{L}_{\text {tabel }}$

Uji Homogenitas Varians

Uji homogenitas varians populasi dilakukan pada penelitian korelasi yang menggunakan teknik analisis regresi. Uji homogenitas varians yang digunakan adalah uji Bartlett dengan taraf signifikansi 0,05. Rangkuman hasil uji Homogenitas Varians dengan uji Bartlett dapat dilihat pada Tabel 5.

Tabel 5. Rangkuman Hasil Uji Homogenitas Varians Galat Regresi dengan Uji Bartlett

\begin{tabular}{cccc}
\hline Persamaan Regresi & $\chi_{\text {hitung }}^{2}$ & $\chi_{\text {tabel }}^{2}$ & Keterangan \\
\hline$Y$ atas $X_{1}$ & $\mathbf{7 , 9 1}$ & $\mathbf{2 1 , 0 0}$ & Homogen \\
Y atas $X_{2}$ & $\mathbf{0 , 0 8}$ & $\mathbf{3 , 8 4}$ & Homogen \\
\hline
\end{tabular}

Berdasarkan hasil perhitungan uji homogentitas variasn di atas ditemukan bahwa harga $\chi_{\text {hitung }}^{2}<\chi_{\text {tabel }}^{2}$ pada taraf nyata 0.05 . Dengan demikian dapat disimpulkan bahwa semua data galat regresi variabel $\mathrm{Y}$ atas $\mathrm{X}$ mempunyai varians yang homogen.

Uji Linearitas Garis Regresi $X_{1}$ dan $X_{2}$ terhadap Y

Uji linearitas adalah uji yang dilakukan untuk melihat apakah masing-masing data variabel status gizi dan kemampuan motorik, cenderung membentuk garis linear terhadap variabel kesegaran jasmani Siswa SD Negeri 06 Pulai Anak Air Kota Bukittinggi. $\mathrm{H}_{\mathrm{o}}$ yang di uji dalam hal ini adalah data status gizi $\left(\mathrm{X}_{1}\right)$, kemampuan motorik $\left(\mathrm{X}_{2}\right)$, memiliki hubungan yang linear dengan kesegaran jasmani Siswa SD Negeri 06 Pulai Anak Air Kota Bukittinggi (Y). kriteria pengujian adalah terima $\mathrm{H}_{\mathrm{o}}$ jika nilai $\mathrm{F}$ hitung yang diperoleh dari perhitungan $<\mathrm{F}$ tabel.
Rangkuman uji linearitas dapat dilihat pada Tabel 6.

Tabel 6. Rangkuman Uji Linearitas Variabel Status Gizi $\left(\mathrm{X}_{1}\right)$, Kemampuan Motorik $\left(\mathrm{X}_{2}\right)$, terhadap Kesegaran Jasmani Siswa (Y)

\begin{tabular}{cccc}
\hline Variabel & $\mathbf{F}_{\text {hitung }}$ & $\begin{array}{c}\mathbf{F}_{\text {tabel }} \boldsymbol{\alpha} \\
=\mathbf{0 . 0 5}\end{array}$ & Kesimpulan \\
\hline $\mathrm{X}_{1}-\mathrm{Y}$ & 1.77 & 2.49 & Linear \\
$\mathrm{X}_{2}-\mathrm{Y}$ & 0.34 & 19.46 & Linear \\
\hline
\end{tabular}

Uji Independensi antar Variabel Bebas

Sebelum sampai pada pengujian hipotesis terlebih dahulu dilakukan perhitungan koefisien korelasi antar variabel bebas yaitu: dalam rangka uji independensi. Rangkuman uji independensi antar variabel bebas dapat dilihat pada Tabel 7.

Tabel 7. Rangkuman Hasil Independensi antar Variabel Bebas

\begin{tabular}{ccccc}
\hline $\begin{array}{c}\text { Korelasi } \\
\text { Antara }\end{array}$ & $\begin{array}{c}\text { Koefisien } \\
\text { Korelasi }\end{array}$ & $\mathrm{t}_{\text {hitung }}$ & $\mathrm{t}_{\text {tabel }}$ & Kesimpulan \\
\hline $\mathrm{X}_{1}-\mathrm{X}_{2}$ & 0.193 & 1.11 & 1.69 & $\begin{array}{c}\text { Tidak } \\
\text { Signifikan }\end{array}$ \\
\hline
\end{tabular}

Berdasarkan uji keberartian korelasi antara status gizi siswa $\left(\mathrm{X}_{1}\right)$ dengan kemampuan motorik siswa $\left(\mathrm{X}_{2}\right)$, sebagaimana pada tabel di atas diperoleh $t_{\text {hitung }}<t_{\text {tabel }}$ pada taraf signifikansi $\alpha=0.05$. Dengan demikian dapat disimpulkan bahwa tidak terdapat hubungan yang signifikan antara status gizi $\left(\mathrm{X}_{1}\right)$ dengan kemampuan motorik $\left(\mathrm{X}_{2}\right)$.

\section{Pengujian Hipotesis}

Setelah uji persyaratan analisis dilakukan dan ternyata semua skor tiap variabel penelitian memenuhi persyaratan untuk dilakukan pengujian statistik lebih lanjut, maka selanjutnya dilaksanakan pengujian hipotesis penelitian, yaitu: (1) status gizi memberikan kontribusi yang signifikan terhadap kesegaran jasmani siswa, (2) kemampuan motorik memberikan kontribusi yang signifikan terhadap kesegaran jasmani siswa, (3) status gizi dan kemampuan motorik secara bersama-sama memberikan kontribusi yang signifikan terhadap kesegaran jasmani siswa. Uji statistik yang digunakan adalah uji regresi pada taraf signifikansi $0.05 \alpha$ untuk lebih jelasnya akan disajikan secara berurutan sebagai berikut. 
Status Gizi Memberikan Kontribusi yang Berarti terhadap Kesegaran Jasmani Siswa SD Negeri 06 Pulai Anak Air Kota Bukittinggi

Hasil analisis menunjukan bahwa status gizi $\left(\mathrm{X}_{1}\right)$ memberikan kontribusi yang berarti terhadap kemampuan Kesegaran Jasmani Siswa SD Negeri 06 Pulai Anak Air Kota Bukittinggi. Nilai persamaan regresinya dapat digambarkan sebagai berikut $\hat{Y}=12,16+0,06 x$ dengan $F_{\text {hitung }}$ $5,24>\mathrm{F}_{\text {tabel }} 4,18$. selanjutnya berdasarkan analisis linearitas regresi diperoleh nilai $\mathrm{F}_{\text {hitung }} 1,77$ $<\mathrm{F}_{\text {tabel }} 2,49$. Hal ini menyatakan bahwa data berada dalam keadaan linear. Dengan demikian hipotesis yang diajukan (Ha) dapat diterima. Untuk lebih jelasnya dapat dilihat pada Tabel 8.

Selanjutnya pada Tabel 9 analisis korelasi data penelitian diperoleh koefisien korelasi pola asuh anak terhadap kemampuan motorik kasar $r_{x 1 y}=0,375$ dengan $t_{\text {hitung }} 2.29>t_{\text {tabel }} 1.69$ menyatakan bahwa terdapat hubungan yang signifikan $\mathrm{X}_{1}$ dengan variabel $\mathrm{Y}$.

Kemudian diperoleh koefisien diterminasi melalui koefisien korelasi dikuadratkan $\mathrm{r}^{2} \mathrm{x}$
$100 \%=0.375^{2} \times 100 \%$ sebesar $14.08 \%$. Artinya bahwa variabel status gizi sebagai independent variabel memberikan kontribusi sebesar 14.08\% terhadap dependent variabel yaitu Kesegaran Jasmani Siswa SD Negeri 06 Pulai Anak Air Kota Bukittinggi.

Kemampuan Motorik Memberikan Kontribusi yang Berarti terhadap Kesegaran Jasmani Siswa SD Negeri 06 Pulai Anak Air Kota Bukittinggi

Hasil analisis menunjukan bahwa kemampuan motorik $\left(\mathrm{X}_{2}\right)$ memberikan kontribusi yang berarti terhadap Kesegaran Jasmani Siswa SD Negeri 06 Pulai Anak Air Kota Bukittinggi. Nilai persamaan regresinya dapat digambarkan sebagai berikut $\hat{\mathrm{Y}}=$ $0,65+0,33 \mathrm{x}$ dengan $\mathrm{F}_{\text {hitung }} 57,68>\mathrm{F}_{\text {tabel }} 4,15$. Selanjutnya berdasarkan analisis linearitas regresi diperoleh nilai $\mathrm{F}_{\text {hitung }} 0,34<\mathrm{F}_{\text {tabel }} 19,46$. Hal ini menyatakan bahwa data berada dalam keadaan linear. Dengan demikian hipotesis yang diajukan (Ha) dapat diterima. Untuk lebih jelasnya dapat dilihat pada Tabel 10.

Tabel 8. Daftar ANAVA Regresi Linear $\hat{Y}=12,16+0,06 x$

\begin{tabular}{lcccccc}
\hline \multicolumn{1}{c}{ Sumber Variasi } & Dk & JK & KT & Fh & Ft $\alpha=\mathbf{0 , 0 5}$ & Kesimpulan \\
\hline Total & 34 & 8852,00 & - & - & & \\
Koefisien (a) & 1 & 8640,12 & - & & & \\
Regresi (b/a) & 1 & 29,83 & 29,83 & 5,24 & 4,15 & Regresi Signifikan (berarti) \\
Sisa & 32 & 182,05 & 5,69 & & & \\
Tuna Cocok & 19 & 131,39 & 6,92 & 1,77 & 2,49 & Regresi Linear \\
Galat & 13 & 50,67 & 3,90 & & & \\
\hline
\end{tabular}

Tabel 9. Uji Signifikansi Korelasi $X_{1}$ dengan $Y$

\begin{tabular}{cccccc}
\hline Korelasi Antara & Koefisien Korelasi & Koefisien Diterminasi & $\mathbf{t}_{\text {hitung }}$ & $\mathbf{t}_{\text {tabel }}$ & Kesimpulan \\
\hline$X_{1}$ dengan $Y$ & 0.375 & $14.08 \%$ & 2.29 & 1.69 & Signifikan \\
\hline
\end{tabular}

Tabel 10. Daftar ANAVA Regresi Linear $\hat{Y}=-3,05+0,38 \mathrm{x}$

\begin{tabular}{lcccccc}
\hline Sumber Variasi & Dk & JK & KT & Fh & Ft $\boldsymbol{\alpha}=\mathbf{0 , 0 5}$ & Kesimpulan \\
\hline Total & 34 & 8852,00 & - & - & & \\
Koefisien (a) & 1 & 8640,12 & - & & & \\
Regresi (b/a) & 1 & 136,28 & 136,28 & 57,68 & 4,15 & Regresi Signifikan (berarti) \\
Sisa & 32 & 75,61 & 2,36 & & & \\
Tuna Cocok & 30 & 63,11 & 2,10 & 0,34 & \multirow{2}{*}{19,46} & Regresi Linear \\
Galat & 2 & 12,50 & 6,25 & & \\
\hline
\end{tabular}

Tabel 11. Uji Signifikansi Korelasi $\mathrm{X}_{2}$ dengan $\mathrm{Y}$

\begin{tabular}{|c|c|c|c|c|c|}
\hline Korelasi Antara & Koefisien Korelasi & Koefisien Diterminasi & $\mathbf{t}_{\text {hitung }}$ & $\mathbf{t}_{\text {tabel }}$ & Kesimpulan \\
\hline $\mathrm{X}_{2}$ dengan $\mathrm{Y}$ & 0.802 & $64.32 \%$ & 7.59 & 1.69 & Signifikan \\
\hline \multicolumn{6}{|c|}{ Tabel 12. Anava Pengujian Signifikansi Regresi Ganda $\hat{Y}=-\mathbf{2 . 0 5}+\mathbf{0 . 0 3} \boldsymbol{X}_{\mathbf{1}}+\mathbf{0 . 3 1} \boldsymbol{X}_{2}$} \\
\hline Sumber V & Dk & JK & & $F_{\text {hitung }}$ & $F_{\text {tabel }}$ \\
\hline Regre & 2 & 147,00 & & 35.11 & 3.31 \\
\hline Sisa & 31 & 64,89 & & 35.11 & \\
\hline Deredu & 34 & & & & \\
\hline
\end{tabular}


Tabel 13. Uji Signifikansi Korelasi $X_{1}$ dan $X_{2}$ dengan $Y$

\begin{tabular}{cccccc}
\hline Korelasi antara & Koefisien korelasi & Koefisien diterminasi & $\mathbf{F}_{\text {hitung }}$ & $\mathbf{F}_{\text {tabel }}$ & Kesimpulan \\
\hline $\mathrm{X}_{1}$ dan $\mathrm{X}_{2}$, dengan $\mathrm{Y}$ & 0.83 & $69.38 \%$ & 35.11 & 3.31 & Signifikan \\
\hline
\end{tabular}

Selanjutnya pada Tabel 11 analisis korelasi data penelitian diperoleh koefisien korelasi kemampuan motorik terhadap kesegaran jasmani $r_{x 1 y}=0,802$ dengan $t_{\text {hitung }} 7.59>t_{\text {tabel }} 1.69$ menyatakan bahwa terdapat hubungan yang signifikan $\mathrm{X}_{2}$ dengan variabel $\mathrm{Y}$.

Kemudian diperoleh koefisien diterminasi melalui koefisien korelasi dikuadratkan $\mathrm{r}^{2} \mathrm{x}$ $100 \%=0.802^{2} \times 100 \%$ sebesar $64.32 \%$. Artinya bahwa variabel kemampuan motorik sebagai independent variabel memberikan kontribusi sebesar $64.32 \%$ terhadap dependent variabel yaitu Kesegaran Jasmani Siswa SD Negeri 06 Pulai Anak Air Kota Bukittinggi.

Status Gizi dan Kemampuan Motorik Secara Bersama-Sama Memberikan Kontribusi yang Berarti terhadap Kesegaran Jasmani Siswa SD Negeri 06 Pulai Anak Air Kota Bukittinggi

Hipotesis yang diajukan dan dirumuskan sebagai berikut: pola status gizi dan kemampuan motorik secara bersama-sama memberikan kontribusi yang berarti terhadap Kesegaran Jasmani Siswa SD Negeri 06 Pulai Anak Air Kota Bukittinggi. Pengujian hipotesis ke tiga ini dilakukan menggunakan analisis regresi ganda dan korelasi ganda. Berdasarkan hasil perhitungan menghasilkan nilai: $\mathbf{b}_{\mathbf{0}}=\mathbf{- 2 . 0 5}, \mathbf{b}_{\mathbf{1}}=\mathbf{0 . 0 3}, \mathbf{b}_{\mathbf{2}}=\mathbf{0 . 3 1}$, dengan demikian persamaan regresi $\mathrm{Y}$ atas $\mathrm{X}_{1}$ dan $\mathrm{X}_{2}$ adalah $\hat{\mathrm{Y}}=\mathbf{- 2 . 0 5}+\mathbf{0 . 0 3} \boldsymbol{X}_{\mathbf{1}}+\mathbf{0 . 3 1} \boldsymbol{X}_{\mathbf{2}}$. Rangkuman uji signifikansi persamaan regresi ganda dapat terlihat pada Tabel 12.

Berdasarkan Tabel 12 dapat dijelaskan uji signifikansi regresi ganda diperoleh $\mathrm{F}_{\text {hitung }}=$ $35.11>\mathrm{F}_{\text {tabel }}=3.31$ artinya persamaan regresi ganda $\hat{\mathrm{Y}}=-\mathbf{2 . 0 5}+0.03 X_{1}+0.31 X_{2}$ adalah signifikan. Dengan demikian maka dapat disimpulkan bahwa status gizi dan kemampuan motorik secara bersama-sama memberikan kontribusi yang berarti terhadap kesegaran jasmani siswa SD Negeri 06 Pulai Anak Air Kota Bukittinggi.

Selanjutnya berdasarkan nilai korelasi $(\mathrm{R})$ sebesar 0.83 kemudian terhadap nilai koefisien korelasi ini dilakukan pengujian signifikansi korelasi dengan menggunakan distribusi $\mathrm{F}$ hasil perhitungan adalah pada tabel 13 .

Berdasarkan uji keberartian korelasi antara pasangan status gizi $\left(\mathrm{X}_{1}\right)$ dan kemampuan motorik $\left(\mathrm{X}_{2}\right)$ secara bersama-sama memberikan kontribusi yang berarti terhadap Kesegaran Jasmani Siswa SD Negeri 06 Pulai Anak Air Kota Bukittinggi (Y) sebagaimana terlihat pada tabel di atas diperoleh $F_{\text {hitung }}(35.11)>F_{\text {tabel }}$ (3.31) pada taraf signifikansi $\alpha=0.05$. Selanjutnya untuk melihat besarnya kontribusi status gizi dan kemampuan motorik secara bersamasama memberikan kontribusi yang berarti terhadap kesegaran jasmani siswa SD Negeri 06 Pulai Anak Air Kota Bukittinggi. dicari melalui koefisien diterminasi $\mathrm{R}^{2}=0,83 \mathrm{x} \quad 100 \%=$ $69,38 \%$. Dengan arti kata status gizi dan kemampuan motorik memberikan kontribusi sebesar $69.38 \%$ terhadap kesegaran jasmani siswa SD Negeri 06 Pulai Anak Air Kota Bukittinggi. Sisanya $30.62 \%$ ditentukan oleh variabel lain yang tidak diperhitungkan dalam penelitian ini.

Berdasarkan hasil pengujian di atas, maka dapat disimpulkan bahwa status gizi dan kemampuan motorik secara bersama-sama memberikan kontribusi yang berarti terhadap Kesegaran Jasmani Siswa SD Negeri 06 Pulai Anak Air Kota Bukittinggi.

\section{Pembahasan}

Penelitian ini dirancang untuk mempelajari hubungan serta berapa besar kontribusi status gizi dan kemampuan motorik terhadap Kesegaran Jasmani Siswa SD Negeri 06 Pulai Anak Air Kota Bukittinggi direfleksikan menggunakan metodologi korelasional dan regresi.

Kontribusi Status Gizi terhadap Kesegaran Jasmani Siswa SD Negeri 06 Pulai Anak Air Kota Bukittinggi

Status gizi merupakan hal yang sangat penting dalam hidup manusia, pada masa anakanak status gizi sangat di butuhkan terutama dalam perkembangan dan pertumbuhan fisik anak, selain itu juga untuk menjaga kesehatan dan kestabilan fisik. Unsur gizi tentu di peroleh dari makanan yang di konsumsi, yang akan digunakan untuk mempertahankan hidup, untuk memperoleh energi guna bekerja dan beraktifitas sehari hari. Bila energi sudah terpenuhi dampaknya akan berpengaruh pada meningkatnya keterampilan fisik seperti belajar gerak motorik dan aktifitas lainnya yang berguna bagi anak sepanjang hidupnya. 
Menurut Mutohir (2004, p. 92) "status gizi adalah suatu kondisi dari setiap individu yang dipengaruhi oleh penggunaan zat makanan, dan dapat di bedakan antara status gizi buruk, kurang, baik dan lebih". Status gizi setiap individu tergantung dari keadaan kesehatan individu-individu atau kelompok-kelompok tersebut yang di tentukan oleh derajat kebutuhan fisik akan energi dan zat-zat gizi lain yang di peroleh dari pangan dan makanan yang dikonsumsinya.

Status gizi siswa yang baik secara tidak langsung akan berdampak terhadap tingkat kesegaran jasmani siswa tersebut. Kesegaran jasmani yang baik sangat bagi seorang siswa karena kesegaran jasmani itu adalah aspek-aspek kemampuan fisik yang dapat menunjang kesuksesan siswa dalam melakukan berbagai aktivitas dalam kehidupan sehari-hari tanpa mengakibatkan kelelahan yang berarti. Kegiatan itu dapat berupa pekerjaan sehari-hari dan untuk keperluan mendadak atau pekerjaan itu dilakukan dalam waktu senggang, karena semakin tinggi tingkat kesegaran jasmani, yang memiliki seseorang maka semakin besar pula kemungkinannya untuk dapat meyesuaikan suatu pekerjaan dan semakin besar pula untuk dapat menikmati kehidupan.

Berdasarkan analisis yang dilakukan terbukti bahwa komponen status gizi memberikan kontribusi sebesar 14,08\% terhadap kesegaran jasmani siswa pada taraf signifikansi $(\alpha) 0.05$. Artinya status gizi memiliki hubungan signifikan dengan kesegaran jasmani siswa. Hal ini bahwa gizi adalah 1/7 faktor yang mempengaruhi kesegaran jasmani. Hal ini sebagaimana yang dikemukakan oleh Gusril (2004, p. 119) berpendapat bahwa tingkat kesegaran jasmani seseorang akan berbeda dan tergantung pada jenis pekerjaan, keadaan kesehatan, jenis kelamin, umur. Jadi jelaslah terlihat bahwa status gizi itu akan mempengaruhi kesegaran jasmani seorang anak. Pengukuran status gizi lebih melihat kepada faktor anatomi tubuh sehingga hasil korelasinya relatif lebih kecil sehingga kontribusinya terhadap kesegaran jasmani hanya $14,08 \%$.

Berdasarkan hasil penelitian dapat disimpulkan bahwa status gizi memberikan pengaruh dan kontribusi terhadap kesegaran jasmani anak. Dimana kesegaran jasmani ini sangat berguna bagi anak dalam melakukan aktivitas fisik sehari-hari dan juga dalam proses belajar dimana kesegaran jasmani akan berpengaruh bagi semangat anak dalam mengikuti proses pembelajaran.
Kontribusi Kemampuan Motorik terhadap Kesegaran Jasmani Siswa SD Negeri 06 Pulai Anak Air Kota Bukittinggi

Kemampuan motorik merupakan landasan keberhasilan dalam melakukan keterampilan dalam olahraga. Tingkat motorik seseorang berbeda-beda tergantung pada banyaknya pengalaman gerak yang dikuasai. Hal itu sesuai dengan pendapat Mutohir (2004, p. 75) sebagai berikut "kemampuan motorik di pandang sebagai landasan keberhasilan masa mendatang di dalam melaksanakan tugas di dalam bidang olah raga dan lain-lain" Seseorang yang memiliki kemampuan motorik tinggi diduga akan dapat lebih berhasil dalam menyelesaikan tugas keterampilan motorik khusus". Kemampuan motorik seseorang berbeda beda sesuai dengan kemampuan orang tersebut, serta memiliki kapasitas yang dipengaruhi oleh faktor biologis.

Kesegaran jasmani merupakan suatu kondisi fisik tubuh dalam mempertahankan atau menyesuaikan fungsi dari alat-alat fisiologis agar dapat beradaptasi dengan lingkungan, sehingga aktifitas yang di lakukan sehari-hari tidak mengalami hambatan, karena tubuh telah mempunyai kondisi yang baik dalam menghadapi hambatan-hambatan tersebut. Makanya seseorang mampu melawan pengaruh-pengaruh luar dan tidak mengurangi efesiensi kondisi badan.

Beberapa anak yang memiliki pengalaman gerak yang banyak dan baik akan memiliki kemampuan motorik yang baik pula. Sedangkan anak-anak yang memiliki pengalaman gerak yang sedikit dan kurang baik, maka anak-anak ini tidak akan memiliki kemampuan motorik yang baik, dan sebagian besar juga tidak akan memiliki kesegaran jasmani yang baik pula. Pengukuran kemampuan motorik diukur dengan keterampilan gerak sehingga hasil korelasinya relatif lebih besar dan berkontribusi terhadap kesegaran jasmani sebesar $64,32 \%$.

Berdasarkan analisis yang dilakukan terbukti bahwa kemampuan motorik memberikan kontribusi sebesar $64,32 \%$ terhadap kesegaran jasmani siswa pada taraf signifikansi $(\alpha) 0.05$. Artinya faktor ini memiliki hubungan signifikan dengan kesegaran jasmani siswa. Kemampuan motorik dapat terlihat dari pengalaman gerak dan keluwesan gerak yang dilakukan oleh sang anak. Kirkendall dalam Gusril, Kiram, Aziz, Hos, \& Darmela (2006) mengemukakan bahwa "kemampuan motorik adalah merupakan kualitas kemampuan sese-orang yang dapat 
mempermudah dalam melakukan keterampilan gerak". Jadi, dari kutip-an tersebut dapat kita ketahui bahwa kemam-puan motorik ini akan mempermudah anak dalam melakukan keterampilan gerak. Sedang-kan keterampilan gerak itu sangar dipengaruhi oleh kesegaran jasmani seseorang.

Berdasarkan bukti dari hasil analisis data dalam penelitian ini, kemampuan motorik merupakan salah satu faktor yang berkontribusi terhadap kesegaran jasmani siswa Sekolah Dasar. Hal ini karena kemampuan motorik akan berpengaruh terhadap keterampilan gerak anak. Dimana aspek keterampilan gerak anak sangat dipengaruhi kesegaran jasmaninya. Selain

Kontribusi Status Gizi dan Kemampuan Motorik Secara Bersama-sama terhadap Kesegaran Jasmani Siswa SD Negeri 06 Pulai Anak Air Kota Bukittinggi

Pada uji hipotesis ketiga yaitu status gizi dan kemampuan motorik secara bersama-sama berkorelasi dengan Kesegaran Jasmani Siswa SD Negeri 06 Pulai Anak Air Kota Bukittinggi secara signifikan. Hal ini dibuktikan oleh koefisien korelasi ganda $(\mathrm{R})$ yang dirumuskan sebesar 0.83. Atas hasil penelitian, ditemukan kontribusi secara bersama-sama antara status gizi dan kemampuan motorik secara bersama-sama berkorelasi dengan kesegaran jasmani siswa SD Negeri 06 Pulai Anak Air Kota Bukittinggi sebesar $69.38 \%$ dan sisanya $30.62 \%$ diperkirakan kontribusi dari faktor lain diantaranya aktivitas bermain, genetik, usia, sarana dan prasarana, serta proses pembelajaran motorik dan lain-lain.

Untuk mengetahui hubungan antar variabel yang mana skor pada suatu variabel dapat digunakan untuk memprediksi skor variabel lainnya dilakukan analisis regresi linear ganda. Dari hasil analisis diperoleh $\hat{\mathrm{Y}}=-2.05+0.03 X_{1}+0.31 X_{2}$. Model persamaan regresi ini mengandung arti bahwa apabila status gizi dan kemampuan motorik ditingkatkan, maka kecendrungan kesegaran jasmani siswa juga akan meningkat

Kesegaran jasmani seorang anak dipengaruhi oleh status gizi dan keterampilan motorik anak. Hal ini karena jika anak mendapat gizi yang baik maka kecenderungan anak untuk tumbuh dan berkembang dengan baik juga akan lebih optimal termasuk dari aspek fisik dan kesegaran jasmaninya. Selain itu, jika anak memiliki pengalaman gerak dan keterampilan motorik yang baik maka itu juga akan menjadi salah satu aspek yang juga dapat mengembangkan kesegaran jasmani siswa.

Dari hasil penelitian didapat bahwa motorik mempunyai pengaruh yang lebih besar terhadap status gizi. Dimana motorik mempunyai pengaruh $64,32 \%$ sedangkan gizi hanya $14,08 \%$. Sehingga dapat dilihat bahwa kemampuan motorik mempunyai pengaruh 4 kali lebih besar terhadap kesegaran jasmani daripada gizi. Hal ini karena kemampuan motorik itu sangat dipengaruhi oleh latihan dan kesegaran jasmani juga sangat dipengaruhi oleh sehingga motorik mempunyai pengaruh yang lebih besar daripada gizi yang sangat dipengaruhi oleh asupan makanan.

Oleh karena itu, status gizi dan kemampuan gerak yang baik, jika dipadukan secara bersama-sama akan menghasilkan kesegaran jasmani anak yang baik pula. Dengan demikian terdapat kontribusi yang signifikan antara status gizi dan kemampuan gerak secara bersama-sama dengan Kesegaran Jasmani Siswa SD Negeri 06 Pulai Anak Air Kota Bukittinggi.

\section{SIMPULAN}

Berdasarkan temuan penelitian dan pembahasan hasil penelitian maka dapat disimpulkan sebagai berikut: (1) Status gizi memberikan kontribusi terhadap kesegaran jasmani siswa SD Negeri 06 Pulai Anak Air Kota Bukittinggi sebesar $14.08 \%$. (2) Kemampuan motorik memberikan kontribusi terhadap kesegaran jasmani siswa SD Negeri 06 Pulai Anak Air Kota Bukittinggi sebesar $64.32 \%$. (3) Status gizi dan kemampuan motorik memberikan kontribusi secara bersama-sama terhadap Kesegaran Jasmani Siswa SD 06 Negeri Pulai Anak Air Kota Bukittinggi sebesar $69.38 \%$.

Dalam upaya peningkatan kesegaran jasmani siswa SD 06 Pulai Anak Air Kota Bukittinggi, dikemukakan saran sebagai berikut: (1) Diharapkan kepada guru Penjasorkes SD Negeri 06 Pulai Anak Air Kota Bukittinggi, untuk dapat menyusun suatu bentuk perencanaan latihan dalam usaha meningkatkan kesegaran jasmani siswanya. (2) Diharapkan kepada orang tua siswa SD Negeri 06 Pulai Anak Air Kota Bukittinggi, agar dapat memperhatikan gizi dan gerak motorik anaknya pada saat berada di luar sekolah. Dengan demikian anak bisa memiliki masa perkembangan dan pertumbuhan yang baik sehingga kesegaran jasmaninya juga baik. (3) Kepada peneliti yang lain untuk selanjutnya dapat mengembangkan penelitian serupa karena penelitian yang dilakukan sangatlah terbatas dari 
segi variabel, jumlah sampel, tempat dan waktu penelitian. Maka diduga masih banyak variabel lain yang turut mendukung terhadap kesegaran jasmani siswa Sekolah Dasar.

\section{DAFTAR PUSTAKA}

Almatsier, S. (2002). Prinsip dasar ilmu gizi. Gramedia Pustaka Utama.

Arsil. (1999). Pembinaan kondisi fisik. Padang: FIK UNP.

Berg, A., \& Nur, Z. D. (1986). Peranan gizi dalam pembangunan nasional. Rajawali, Jakarta.

Departemen Pendidikan Nasional. (2008). Kamus Besar Bahasa Indonesia. Jakarta: Pusat Bahasa, Departemen Pendidikan Nasional.

Gusril. (2004). Perkembangan motorik pada masa anak-anak. Jakarta: Departemen Pendidikan Nasional.

Gusril, G., Kiram, Y., Aziz, S., Hos, F., \& Darmela, L. (2006). Model pengembangan motorik siswa sekolah dasar. Padang: FIK UNP. Retrieved from http://repository.unp.ac.id/308/

Hurlock, E. B., Istiwidayanti, Sijabat, R. M., \& Soedjarwo. (1990). Psikologi perkembangan: Suatu pendekatan sepanjang rentang kehidupan. Erlangga, Jakarta.

Ihsan, N. (2014). The analysis of the physical condition, will pencak silat construction training center students (PPLP) of West Sumatra. In International Seminar of Sport
Culture and Achievement (p. 307).

Kiram, Y. (1992). Belajar Motorik. Jakarta: Proyek Pembinaan Tenaga Kependidikan Ditjen Dikti Depdikbud.

Lutan, R. (1988). Belajar keterampilan motorik, pengantar teori dan metode. Depdikbud Dirjen Dikti PPLPTK. Jakarta.

Mikdar, U. Z. (2006). Hidup sehat: nilai inti berolahraga. Jakarta: Departemen Pendidikan Nasional, Direktorat Jendral Pendidikan Tinggi, Direktorat Ketenagaan.

Mutohir, T. C. (2004). Perkembangan Motorik pada Masa Anak-Anak. Jakarta: Proyek Pengembangan dan Keserasian Kebijakan Olahraga, Direktorat Jenderal Olahraga, Depdikanas.

Presiden Republik Indonesia. Undang-Undang Republik Indonesia nomor 20 tahun 2003 tentang sistem pendidikan nasional, Pub. L. No. 20, 26 (2003). Indonesia. Retrieved from http://sindikker.dikti.go.id/dok/UU/UU202003-Sisdiknas.pdf

Sukadiyanto, S. (1997). Penentuan tahap kemampuan motorik anak sekolah dasar. Yogyakarta: FPOK IKIP.Yogyakarta.

Supariasa, I. D. N., Bakri, B., \& Fajar, I. (2002). Penilaian status gizi. Jakarta: EGC, 48-49.

Suryabrata, S. (2000). Pengembangan alat ukur psikologis. Yogyakarta: Andi.

Wirjatmadi, B. (1998). Penilaian Status Gizi. Surabaya: IRM UNAIR. 